\title{
INVESTIGATIONS CONCERNING E-GOVERNMENT ADOPTION IN TRANSITION ECONOMIES
}

\author{
Zsuzsanna Katalin SZABÓ - Lucian CHIRIAC \\ (Received: 7 February 2014; revision received: 26 July 2014; \\ accepted: 26 August 2014)
}

\begin{abstract}
The implementation of efficient cross-border digital public services for a connected Europe, a developed e-government represents a priority for the European Union. There are big differences in the way e-government is adopted. Transition economies lag behind developed economies. This paper explores the e-government adoption in its multidimensionality within the EU member states. It uses 22 variables, which highlight: technological preparedness, the ability to access and absorb information and information technology, the ability to generate, adopt and spread knowledge, the social and legal environment, the government policy and vision, and consumer and business adoption and innovation. Barriers to efficient e-government adoption in transition economies are identified. Multicriteria decision analysis is used for the prioritisation of the factors with the highest overall impact on efficient implementation. The authors use the Analytical Hierarchy Process (AHP method) for prioritisation and the numerical results are obtained with Expert Choice software.
\end{abstract}

Keywords: e-government, key success factors, AHP, prioritisation, policy options

JEL classification indices: $\mathrm{C} 02, \mathrm{O} 11, \mathrm{O} 32, \mathrm{O} 57$

Zsuzsanna Katalin Szabó, corresponding author. Assistant Professor at the Faculty of Economics, Law and Administrative Sciences, "Petru Maior" University of Tirgu Mures, Romania.

E-mail: szabo.zs.katalin@gmail.com

Lucian Chiriac, Professor at the Faculty of Economics, Law and Administrative Sciences, "Petru Maior” University of Tirgu Mures, Romania. E-mail: lucian.chiriac@ea.upm.ro 


\section{INTRODUCTION}

The e-government development has become a thoroughly discussed issue among practitioners and a burning research topic among researchers and academics. Many research studies analysed different aspects of the e-government (Selhofer - Mayringer 2001; Zhiyuan 2002; Cuervo - Menéndez 2005; Andoh-Baidoo Lawrencia 2011; Soukup 2013). Measurement methods were formulated in order to have quantitative evidence to evaluate the level of the development and to compare efficiency and performance (Vintar et al. 2002). Different systems of indicators were built in order to measure the level of implementation, the development, the level of usage, the quality of the offered services, to evaluate the preparedness on the technical, socio-cultural and government level, and to evaluate the "e-readiness" of the countries. In 2013, a pilot exercise was published by the European Public Sector Innovation Scoreboard (Hollanders et al. 2013). The Scoreboard defined innovation in public administration and formulated a measurement framework.

In order to evaluate the necessities and to formulate adequate policies, it is important to know the role/the involvement/the ability of the government, businesses and individuals to use ICT to their benefit. Policies must follow priorities such as diffusion of knowledge, enlargement of innovation support, mission oriented strategies, upgrading human resources, access to skills and competencies, abilities to learn, promotion of organisational change, technological change, productivity, and competitiveness.

This paper will examine the efficiency of e-government adoption in transition economies in the European context and will identify barriers to its implementation. The main research objectives of the study will be grouped in four research topics in Section 2. The methodology and the data used will be disclosed in Section 3. The results of the research - a detailed analysis of e-government adoption - will be presented in Section 4, while the prioritisation of the factors with the highest overall impact on the successful implementation of e-government, using the AHP method (Analytical Hierarchy Process), will be described in Section 5. Conclusions will be formulated in Section 6.

\section{RESEARCH QUESTIONS AND OBJECTIVES}

There are huge differences worldwide in the level of e-government development, although there is a clear tendency of best practice adoptions. Europe is the leader in the world and all European regions are ranked higher than the world average. 
Table 1. E-government Development Index (EGDI), region-rankings and scores

\begin{tabular}{lcc}
\hline & 2010 & 2012 \\
\hline Europe & 0.5937 & 0.7188 \\
USA & 0.4790 & 0.5403 \\
Asia & 0.4330 & 0.4922 \\
Oceania & 0.2695 & 0.4240 \\
Africa & 0.2681 & 0.2944 \\
World average & 0.4200 & 0.4959 \\
\hline
\end{tabular}

Note: EGDI is a weighted average of three normalised scores on the three most important dimensions of e-government, namely (1) scope and quality of online services (Online Service Index, OSI), (2) development status of telecommunication infrastructure (Telecommunication Infrastructure Index, TII), and (3) inherent human capital (Human Capital Index, HCI). EGDI = 1/3 (OSI normalised + TII normalised + HCI normalised)

Source: United Nations e-Government Development Database (http://unpan3.un.org).

In Europe, e-government presents a viable alternative channel for public service delivery, yet, although "e-government has now matured in most developed European countries, transition economies in Europe have only recently begun to recognise its potential benefits" (Weerakkodya et al. 2012: 66). The Global E-government Development Index shows that there are also big differences between regions in Europe, as can be seen in Table 2.

Table 2. E-government Development Index (EGDI), Europe-rankings and scores

\begin{tabular}{lll}
\hline & 2010 & 2012 \\
\hline Western Europe & 0.6369 & 0.8142 \\
Northern Europe & 0.7113 & 0.8045 \\
Southern Europe & 0.5168 & 0.6574 \\
Eastern Europe & 0.5449 & 0.6333 \\
Europe average & 0.5937 & 0.7188 \\
\hline
\end{tabular}

Source: United Nations e-Government Development Database (http://unpan3.un.org).

Eastern European countries lag behind in Europe, and the rate of progress in the calculated score (2012 vs.2010) was small (14\%); smaller than in Southern or Western Europe (21\% and 22\%, respectively).

Developed e-government and cross-border digital public services for a connected Europe represent a priority for the European Commission (EC 2013b). The problem of how the gap between European countries can be reduced was addressed in different research papers. ${ }^{1}$

For selected transition economies: Spremić et al. (2010), for the transition economies of Central and Eastern Europe: Ifinedo - Singh (2011), for the Balkans: Matei - Savulescu (2011), for Romania: Gatman (2011), and for Poland: Ziemba et al. (2013). 
The present study is focused on the following main research topics:

Question 1: A successful adoption of e-government is determined by the stages of economic development. There is a strong positive relationship between the successful implementation of e-government and the level of development of the information society and knowledge-based economy. The successful implementation of e-government requires a developed information society, a developed knowledge-based economy.

Question 2: The ability of economies to participate in the information revolution is determined by the nations' degree of preparation to participate in and benefit from information and communication technology developments; by "the degree to which a country, nation or economy may be ready, willing or prepared to obtain benefits which arise from information and communication technologies" (Danish 2006: 1) and by the country's capability to manage change (EIU 2009).

Question 3: The readiness for the adoption of e-government and the level of implementation show big differences between transition and developed economies. Legislation can be expected to play a significant role in the success of implementation. In order to explore the e-government adoption, implementation in its multidimensionality, it is possible to use 22 variables, which highlight technological preparedness, ability to access and absorb information and information technology, the ability to generate, adopt and diffuse knowledge, the social and legal environment, government policy and vision, consumer and business adoption, and innovation. To gauge the relationship between the level of e-government adoption, various indicators will be analysed such as the E-readiness Index, the Network Readiness Index (NRI), the Summary Innovation Index (SII), the digital agenda scoreboard, and the knowledge assessment methodology (KAM) created by the World Bank, the ICT-Opportunity Index, the Information Society Development Index (IDI) published by the Information Technology Unit (ITU), the Global E-government Development Index of the UN member states, the Global Competitiveness Index (GCI), and GDP/capita. The critical success factors of e-government adoption in transition economies will be identified.

Question 4: The critical success factors for e-government adoption in transition economies can be assigned to different categories. A hierarchy model of success factors can be made and multi-criteria decision analysis can be used for the prioritisation of the factors with the highest overall impact on efficient implementation. The method can serve as a useful instrument for policymakers in the decision-making process. 


\section{METHODOLOGY AND DATA USED}

We used publicly available databases such as (i) Knowledge Assessment Methodology (World Bank 2012), an on-line tool created by the World Bank. (ii) The Information and Communication Technology Opportunity Index (ICT-OI) is an important tool to track the digital divide by measuring the relative differences in ICT (ITU). It is calculated using four sub-indices (network index, skills index, uptake index, intensity index). Another database has been published by the Information Technology Union (ITU) since 2009 to measure the Information Society using the ICT development index (IDI) and ICT price basket (IPB) (ITU 2013). (iii) The Global Competitiveness Index introduced by Sala-i-Martin (2004), which assigns the economies to development stages, the countries rank is published annually by the World Economic Forum (WEF), using different indicators grouped in 12 pillars. According to the Global Competitiveness Report 2013-2014, using the global competitiveness index (GCI), Romania and Bulgaria are efficiency-driven economies (stage 2), Estonia, Hungary, Latvia, Lithuania, Poland, Croatia, and Slovakia are economies in transition from stage 2 to stage 3, and the other EU member states are innovation-driven economies (stage 3) (Schwab - WEF 2013-2014).

The Innovation Union Scoreboard (2012-2013), which gives a comparative assessment of the innovation performance of EU member states based on the Summary Innovation Index (SII), lists the countries according to four performance groups. The least performance group, the "modest innovators", comprise Poland, Romania, Latvia, and Bulgaria (Hollanders - Es-Sadki 2013). The European Public Sector Innovation Scoreboard (EPSIS) is a pilot exercise (Hollanders et al. 2013).

The Global Information Technology Report 2013 is a project within the framework of the World Economic Forum (WEF) and INSEAD, which publishes the Network Readiness Index (NRI), defined as a nation's or community's degree of preparation to participate in and benefit from information and communication technology developments. It is published since 2000-2001; it was introduced by Kirkman et al. (2002) and redefined by Dutta et al. (2013). The E-Government Development Index (EGDI) is published by the United Nations (UN 2012). The e-readiness and Digital Economy rankings have been published since 2000 by the Economist Intelligence Unit (IBM - EIU, Digital Economy Rankings 2010). The Change Readiness Index measures countries' abilities to manage change and cultivate opportunity through the social, governance, and economic capabilities (KPMG - ODI 2012). The Waseda University International e-government ranking uses 7 main indicators, built on 30 sub-indicators to evaluate the e-government development of countries in the world (Waseda 2013). The Digital Agenda Score- 
board valuates the progress made in achieving the digital agenda for Europe's goals (EC, Digital Agenda Scoreboard 2013).

In our paper, regression analysis was employed to verify the relationships suggested by the hypotheses. To measure the strength of the association between two ranked variables, the Spearman's rank-order correlation $(\rho)$ was calculated. The selection of variables usually follows logic and rational paradigms. For data processing, the SPSS software package was used. The numerical results for AHP method were obtained by Expert Choice.

\section{RESULTS AND ANALYSIS}

To highlight the heterogeneity of the e-government adoption in the EU member states, a descriptive analysis of the selected 22 indicators was used for $27 \mathrm{EU}$ member states ${ }^{2}$ (see Appendix).

Regarding Question 1, our results show (Figure 1) that the development level of e-government is correlated with the development stages of the economy.

The World Economic Forum provides detailed evaluations of the productive potential of economies worldwide and allocates countries into stages of development based on the Global Competitiveness Index (GCI). The Schwab - WEF Report (2013-2014) ranks 148 economies. The competitiveness performance of the countries is based on the 12 most important pillars. These pillars represent certain stages of economic and social development, from factor-driven economies through efficiency-driven economies to innovation-driven economies as the more competitive ones. Romania (ranked at the $76^{\text {th }}$ position in 2013/2014 and at the $67^{\text {th }}$ in 2010) and Bulgaria were assigned to the efficiency-driven economies. The situation worsened on the "basic requirements" sub-indices and on "innovation-sophistication" factors. These are the reasons why Romania lags behind EU countries. Estonia, Hungary, Poland, Latvia, Lithuania, Croatia, and the Slovak Republic were assigned to the transition stage, from the efficiency-driven stage to innovation-driven economies.

In countries assigned to the innovation driven stage, e-government adoption and information society are also highly developed. To measure the strength of the connection between information society (IDI), knowledge-based society (KEI), the development stage of the economy (GCI) and the level of e-government adoption (eGDI-UN), Spearman's rank-order correlation was used. Examining the obtained results, a positive strong relationship is revealed between the indices, as we can see from Table 3.

2 Croatia's data are missing. 


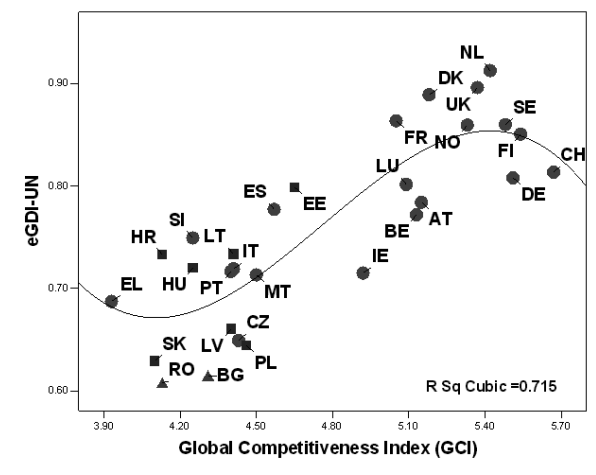

Figure 1. Correlation between GCI and eGDI-UN

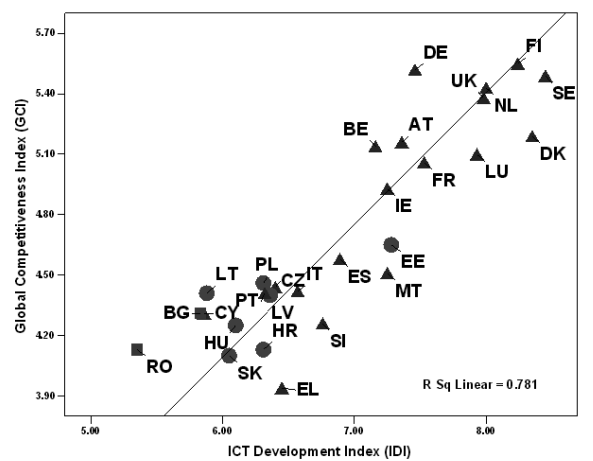

Figure 2. Correlation between IDI and GCI

Source: Own calculations based on UN (2014), Schwab - WEF (2013-2014), and IBM - EIU (2009).

A positive strong linear relationship was identified between the level of information society and the development stage of the economy $\left(\mathrm{R}^{2}=0.781\right.$, Figure 2$)$. In countries with developed e-government, the information society is also highly developed. A developed ICT environment has a positive impact on international competitiveness and on the stage of economic development.

Analysing the European transition economies, it can be observed that Romania and Bulgaria lag behind other transition economies, thus the identification of the main problems represents a priority. In transition economies, policies are needed in order to develop a knowledge-based economy and information society, as can be seen in Figures 3 and 4. The knowledge-managed economy is the latest "new economy", which is characterised by "globalisation, an economy with the capacity to innovate and the intensity of usage of information and knowledge"

Table 3. The strength of connection between GCI, KEI, and IDI

\begin{tabular}{lccc}
\hline $\begin{array}{l}\text { Spearman's rank-order } \\
\text { correlation }\end{array}$ & $\begin{array}{c}\text { Development stages } \\
\text { of the economy (GCI) }\end{array}$ & $\begin{array}{c}\text { Knowledge economy } \\
\text { development (KEI) }\end{array}$ & $\begin{array}{c}\text { Information society } \\
\text { development (IDI) }\end{array}$ \\
\hline eGDI-UN & 0.787 & 0.815 & 0.854 \\
$\begin{array}{l}\text { Development stages } \\
\text { of the economy (GCI) }\end{array}$ & & 0.872 & 0.863 \\
$\begin{array}{l}\text { Knowledge economy } \\
\text { development (KEI) }\end{array}$ & & & 0.883 \\
\hline
\end{tabular}

Note: Correlation is significant at the 0.01 level.

Source: Own calculations based on UN (2014), Schwab - WEF (2013-2014), ITU (2013), IBM - EIU (2009), and World Bank (2012). 


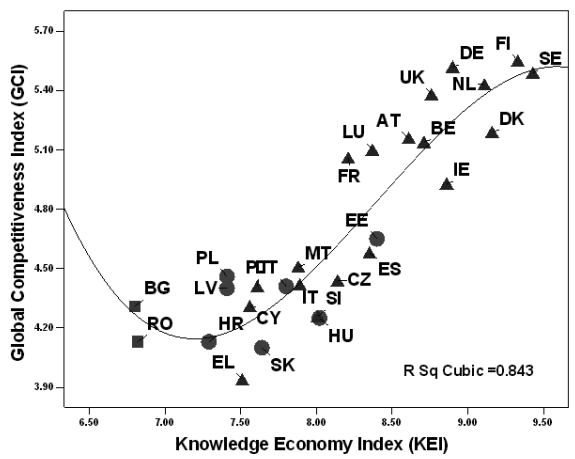

Figure 3. Correlation between GCI and KEI

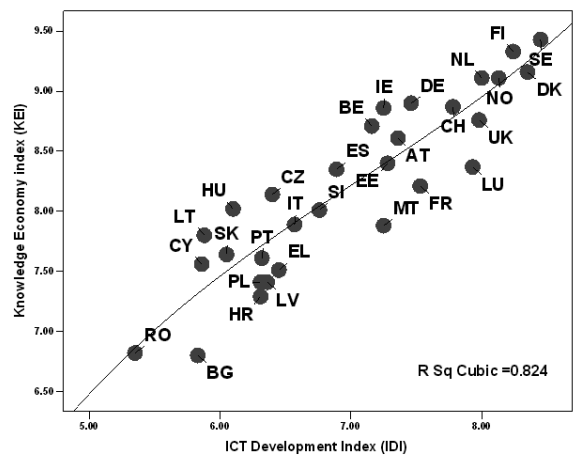

Figure 4. Correlation between IDI and KEI

Source: Own calculations based on Schwab - WEF (2013-2014), ITU (2013), and World Bank (2012).

(Jindřich 2013: 1302). E-government cannot achieve high performances while the technological, social, cultural, and legal environment is not sufficiently developed and consumer skills and abilities are at a low level.

To study Question 2, the Network Readiness Index (NRI) was used. The NRI is a composite index, built on 4 sub-indices (environment, readiness, usage, and impact) incorporating 54 indicators in all. The methodology aim is to evaluate the level of digitisation and its impact on economy, society, and governance. Since 2000, the Economist Intelligence Unit (EIU) has measured countries' ability to absorb ICT and to use it for social and economic benefit. From 2010, the study was renamed digital economy ranking. The model consists of 6 dimensions (connectivity, business environment, social and cultural environment, legal environment, government policy and vision, and consumer and business adoption) and incorporates over 100 separate quantitative and qualitative criteria. A positive strong relationship was identified between the NRI and e-government development (eGDI-UN), the calculated Spearman correlation coefficient is $\rho=0.882$ (the correlation is significant at the 0.01 level). Strong positive relationships exist also between the level of e-government development and e-readiness (the calculated Spearman coefficient is $\rho=0.888, \mathrm{p}<0.01$ ).

The NRI and e-readiness capture different aspects of the digitisation level. A very strong positive relationship was identified between the indices: economies with a high NRI value also have a high e-readiness score (Figure 5).

Table 4 presents how efficient e-readiness is in the transition economies compared to Denmark in 2009 and Sweden in 2010. The features of the transition countries changed slightly during two years, which was only sufficient to maintain approximately the same position in ranking. The gap is narrowing extremely 


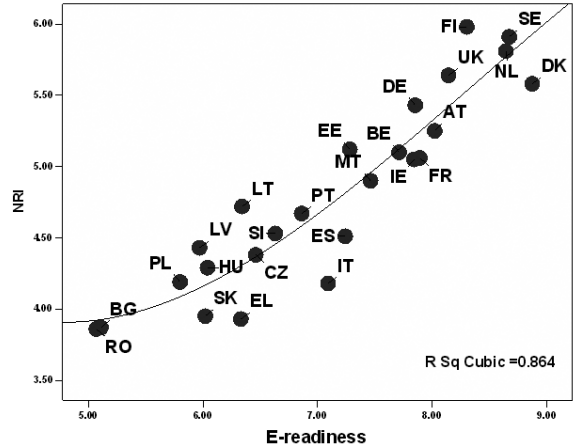

Figure 5. Correlation between NRI and e-readiness
Table 4. Efficiency of e-readiness compared to Denmark and Sweden

\begin{tabular}{l|l|l}
\hline \multirow{2}{*}{ Countries } & \multicolumn{2}{|l}{ e-readiness (EIU), \% } \\
\cline { 2 - 3 } & 2009 & 2010 \\
\hline RO & 58.48 & 59.36 \\
\hline BG & 58.94 & 59.48 \\
\hline PL & 66.90 & 67.13 \\
\hline SK & 69.43 & 68.08 \\
\hline HU & 69.67 & 71.37 \\
\hline CZ & 74.51 & 74.08 \\
\hline LT & 73.13 & 72.32 \\
\hline LV & 68.86 & 68.19 \\
\hline
\end{tabular}

Source: Own calculations based on Bilbao et al. (2013) and IBM - EIU (2009).

slowly between the top-ranked and the bottom-ranked country. Transition economies moved down significantly concerning the preparation to participate in and benefit from ICT development as can be seen in Figures 6 and 7. Regarding egovernment development, the changes concerning efficiency are not significant and the countries' position in ranking worsened in 2012 as compared with 2010.

Longitudinal data present quantitative evidence supporting the fact that of all the transition economies, Romania and Bulgaria, lag behind their peer countries. These countries' position decreased annually compared to the others', demonstrating that countries did not develop at the same rate. This means that barriers exist as well as factors that hinder these countries from achieving high performances (Table 5).

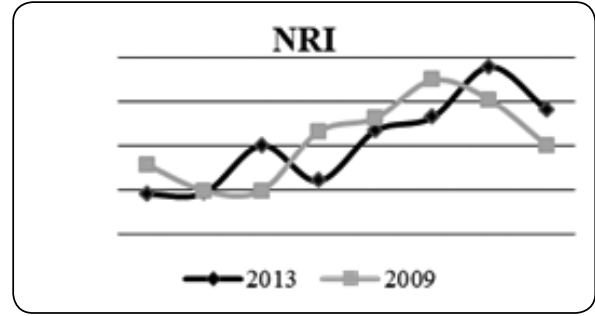

Figure 6. Transition economies' preparation to benefit from ICT

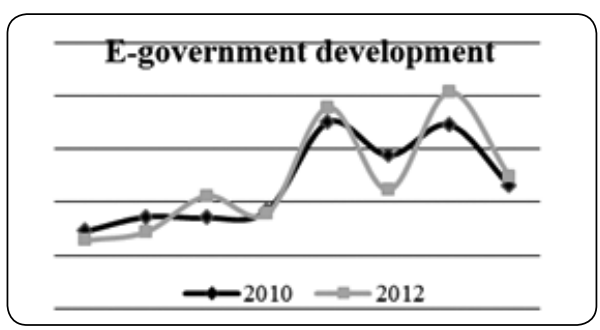

Figure 7. E-government development in the transiton countries

Source: Own calculations based on Bilbao et al.(2013) and UN (2014). 
Table 5. Transition economies' preparation to participate in and benefit from ICT development

\begin{tabular}{l|l|c|c|c|c|c|c|c|c|c}
\hline Overall Rank & Year & Total* & RO & BG & PL & SK & HU & CZ & LT & LV \\
\hline \multirow{4}{*}{ NRI (WEF) } & 2013 & 144 & 75 & 71 & 49 & 61 & 44 & 42 & 32 & 41 \\
\cline { 2 - 13 } & 2012 & 142 & 67 & 70 & 49 & 64 & 43 & 42 & 31 & 41 \\
\cline { 2 - 12 } & 2011 & 138 & 65 & 68 & 62 & 69 & 49 & 40 & 42 & 52 \\
\cline { 2 - 12 } & 2009 & 134 & 58 & 68 & 69 & 43 & 41 & 32 & 35 & 48 \\
\hline \multirow{5}{*}{ e-readiness (EIU) } & 2010 & 70 & 47 & 45 & 39 & 38 & 35 & 31 & 34 & 37 \\
\cline { 2 - 12 } & 2009 & 70 & 48 & 47 & 39 & 36 & 35 & 31 & 32 & 37 \\
\cline { 2 - 12 } & 2008 & 70 & 45 & 48 & 41 & 36 & 33 & 31 & 38 & 37 \\
\cline { 2 - 11 } & 2006 & 68 & 49 & 44 & 34 & 36 & 32 & 32 & 38 & 39 \\
\hline \multirow{3}{*}{$\begin{array}{l}\text { e-government } \\
\text { development (UN) }\end{array}$} & 2012 & 190 & 62 & 60 & 47 & 53 & 31 & 46 & 29 & 42 \\
\cline { 2 - 11 } & 2010 & 183 & 47 & 44 & 45 & 43 & 27 & 33 & 28 & 37 \\
\cline { 2 - 10 } & 2008 & 192 & 51 & 43 & 33 & 38 & 30 & 25 & 28 & 36 \\
\hline
\end{tabular}

Note: *The number of the countries in the ranking.

Source: Own calculations based on Bilbao et al. (2013), IBM - EIU (2009), and UN (2014).

The Change Readiness Index published in 2012 measured the level of change across 60 countries worldwide. Romania was ranked $44^{\text {th }}\left(48^{\text {th }}\right.$ position on the economic, $49^{\text {th }}$ position on the governance, and $26^{\text {th }}$ position on the social subindex). The governance capabilities sub-index relates the capacity of the government and the institutional arrangement to manage the change.

The ICT-Opportunity Index (ICT-OI) is calculated as a composite index of four sub-indices (network, skills, uptake, and intensity). It is an important tool to track the digital divide by measuring the relative differences in ICT. A very strong positive relationship was identified between the e-readiness and ICT-OI (used to measure information society), the Spearman coefficient is $\rho=0.936, p<$ 0.01 , and a high ICT-OI means a developed e-government, having $\rho$ (ICT-OI and eGDI-UN) $=0.847$.

Regarding Question 3, the explanatory power of the collected indices was evaluated. A strong or very strong positive correlation was identified between the variables, as can be seen in Table 3 and Table 6. The composite indicators of the considered indices were studied also to identify the barriers to efficient e-government implementation in transition economies.

In e-government rankings, the leader countries are innovation-driven economies with high innovative capacity and performance (SE, FI, DK, NL). Our results reveal a linear correlation between the level of the e-government development and innovation, measured by summary innovation index, $\operatorname{SII}\left(\mathrm{R}^{2}=0.71\right.$ and the Spearman $\rho=0.838, p<0.01)$. The transition economies' innovative capacity and performance is at a low level (Szabó et al. 2013). 
Table 6. Spearman rank correlation in the sample

\begin{tabular}{|c|c|c|c|c|c|c|}
\hline 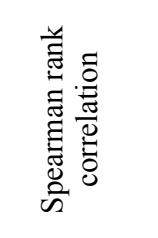 & 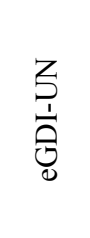 & 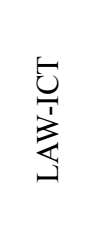 & 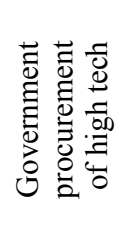 & 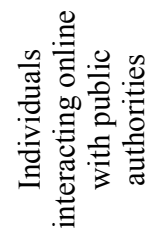 & 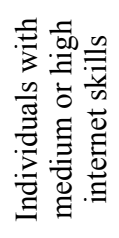 & 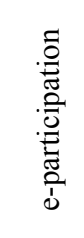 \\
\hline eGDI-UN & 1.000 & 0.757 & 0.845 & 0.808 & 0.584 & 0.853 \\
\hline NRI & 0.872 & 0.887 & 0.858 & 0.829 & 0.634 & 0.711 \\
\hline e-readiness & 0.888 & 0.835 & 0.722 & 0.801 & 0.489 & 0.696 \\
\hline ICT-OI & 0.847 & 0.816 & 0.758 & 0.803 & 0.554 & 0.581 \\
\hline IDI & 0.854 & 0.800 & 0.691 & 0.850 & 0.572 & 0.711 \\
\hline KEI & 0.815 & 0.762 & 0.660 & 0.813 & 0.527 & 0.668 \\
\hline SII & 0.838 & 0.705 & 0.680 & 0.773 & 0.417 & 0.577 \\
\hline KI & 0.824 & 0.682 & 0.600 & 0.779 & 0.445 & 0.671 \\
\hline
\end{tabular}

Note: Correlation is significant at the 0.01 level.

Source: Own calculations based on Bilbao et al. (2013), World Bank (2012), UN (2014), Schwab (2013-2014), IBM - EIU (2009), Hollanders - Es-Sadki (2013), and ITU (2013).

Countries with a high SII score have a developed e-government (Figure 8), which implies large e-participation (strong positive relationship was identified, $\rho=0.853$, as can be seen in Table 6). Thus, for transition economies, innovation can be considered a barrier to efficient implementation.

The European Public Sector Scoreboard (EPSIS) (Hollanders et al. 2013) considers the following barriers to innovation in public administration: the lack of

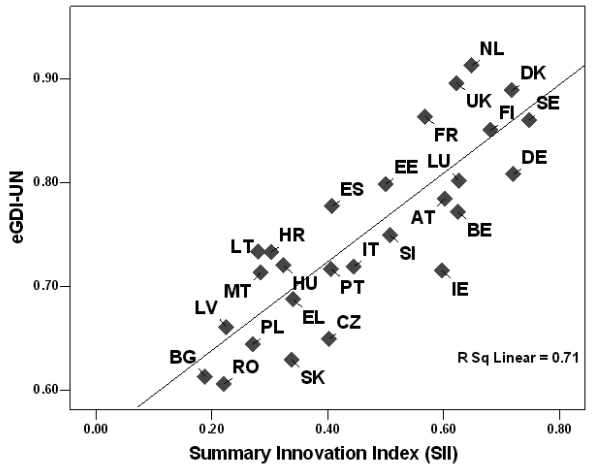

Figure 8 . The correlation between SII and eGDI-UN

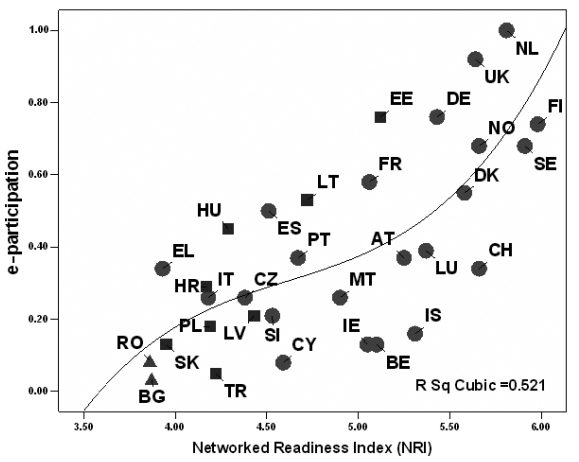

Figure 9. The correlation between NRI and e-participation

Source: Own calculations based on Hollanders - Es-Sadki (2013), UN (2014), Schwab (2013-2014), Bilbao et al. (2013), and Hollanders - Es-Sadki (2013). 
human or financial resources, regulatory requirements, lack of management support, lack of incentives for staff, and lack of funding. Innovation in public administration institutions, at the EU level, is considered the introduction of a new or significantly improved service in the last 3 years; the single and most important driver of innovation in the public sector is considered the introduction of new laws and regulations, followed by new policy priorities and mandated implementations of an online service provision (Chilea 2004). Our results (Table 6) present quantitative evidence in this respect. The correlation between the cyber law/laws relating to ICTs and the considered variables is strong or very strong, having values between 0.7 and 0.9 .

The most important role of innovation in public administration is formulated by EPSIS: "innovations improve the work of public administration - improved user access to information due to service innovations, improved user satisfaction; more targeted services, a faster delivery of services; simplified administration; improved working conditions or employee satisfaction and cost reductions" (Hollanders et al. 2013: 16). In order to measure innovation in public administration, 22 indicators were grouped in 3 sub-indices: enablers, activities, and outputs. EPSIS indicators reveal that Hungary is in the last place in the case of 8 indicators, enrolled in all 3 sub-indices. Romania is in the last position between transition economies on 5 indicators (government effectiveness, regulatory quality, increased efficiency of government services due to the use of ICT, online availability of public services, and e-government development index, eGDI-UN), which measure the quality of public services.

The NRI 2013 placed Romania in $106^{\text {th }}$ place out of 144 countries, on the $1^{\text {st }}$ pillar: political and regulatory environment. In terms of the indicator "laws relating to ICTs", it was ranked at the $88^{\text {th }}$ position: thus, for this country, one of the key success factors is the cyber law/laws relating to ICTs.

Network preparadness is considered the basic infrastructural foundation for effective e-government implementation (Waseda 2013). ${ }^{3}$ Our results (Table 6) present quantitative evidence in this respect. A very strong positive relationship was identified between the NRI and e-government development, cyber law, and

3 The Waseda University has been monitoring e-government development worldwide since 2002. The latest edition of the International e-Government Ranking surveyed 55 countries (Waseda 2013). From the EU countries included in the study, Finland, Sweden, Denmark, and the Netherlands were considered as leaders. The Czech Republic and Romania, which were included in the lower scoring group (score under 50 from the totally 100 possible) ranked at the $38^{\text {th }}$ and $42^{\text {th }}$ position, respectively. Seven main indicators were used to rank the countries (network preparadness, required interface-functioning applications, management optimisation, national portal/homepage, CIO in government, e-government promotion, and e-participation-digital inclusion), which were calculated by weighting 30 dimensions. 
individuals interacting with public authorities. Longitudinal data (Table 5) shows that the overall rank of Romania, Bulgaria, and Slovakia worsened. The level of the countries' preparation to participate in and benefit from ICT developments is significant, thus for transition economies, the political and regulatory environment ( $1^{\text {st }}$ pillar), government usage ( $8^{\text {th }}$ pillar), economic impacts ( $9^{\text {th }}$ pillar), and social impacts $\left(10^{\text {th }}\right.$ pillar) can be considered barriers.

Our results reveal a very strong positive relation between the level of e-government development and e-participation (Table 6). According to the Waseda e-government ranking, e-participation "is a term referring to ICT supported participation in government and governance processes. Processes may be concerned with administration, service delivery, decision making and policy making". The WEF defines it as "the quality, relevance and usefulness of government websites in providing online information and participatory tools and services to their citizens", and it is a component of the $10^{\text {th }}$ pillar (social impacts) of NRI (BilbaoOsorio et al. 2013). As can be seen in Figure 9, e-participation is at a high level in countries with a high NRI value.

To ensure the citizens' efficient participation, the basic public services must be fully available online. In transition economies, the basic public services are not fully available. Furthermore, there is a huge gap between the availabilty of online public services and the level of usage. The percentage of individuals interacting online with public authorities is less than the availability and the percentage of individuals returning filled forms to public authorities is significantly less. Based on data published by the Digital Agenda Scoreboard (EC 2013a), the use of egovernment services by citizens showed a moderate growth between 2011 and 2012 in the EU (from 41\% to 44\%). A large increase was recorded in Romania (24 percentage points), but despite this, the country is below the EU average in this respect. The highest percentage of individuals who never used the internet is in Romania: $48 \%$ of the population. The barriers to the interactive usage of e-government services are as follows: citizens preferred to have personal contacts $(59 \%)$, services will require personal visits $(41 \%)$, abandoned because of technical failure (8\%) and difficulty of use (8\%), unawareness of relevant websites/ online services (24\%), security concerns (11\%), and no expectation of saving time by using the internet $(6 \%)$. The percentage of households with no access to the internet is under EU average in transition economies.

A strong positive relationship was identified between the percentage of individuals interacting online with public authorities and the level of e-government development, NRI, e-readiness, the development level of information society, and knowledge (the calculated Spearman rank correlation coefficient can be seen in Table 6). Thus another key success factor is knowledge (to generate, adopt, and diffuse knowledge) (WB 2013). 


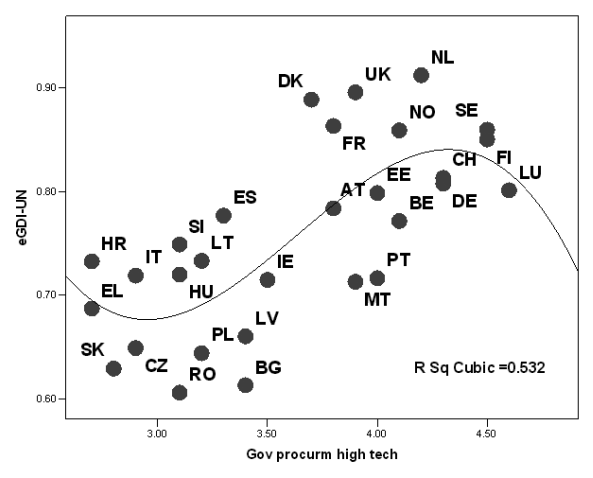

Figure 10. The correlation between government high technology procurement and eGDI-UN
Table 7. The calculated Spearman rank correlation

\begin{tabular}{lc}
\hline $\begin{array}{c}\text { Spearman rank } \\
\text { correlation } \rho\end{array}$ & GDP/capita \\
\hline eGDI-UN & 0.739 \\
KEI & 0.848 \\
IDI & 0.849 \\
NRI & 0.782 \\
e-readiness & 0.922 \\
KI & 0.861 \\
SII & 0.927 \\
Innovation (WB) & 0.911 \\
ICT (WB) & 0.821 \\
ICT-OI (ITU) & 0.897 \\
\hline
\end{tabular}

Source: Own calculations based on Bilbao et al. (2013), UN (2014), Hollanders - Es-Sadki (2013), ITU (2013), and World Bank (2012).

Data provided by digital economy ranking show that the efficiency with which Romania operates in terms of the social and cultural environment is $61.31 \%$ of the leader country (Sweden) efficiency (IBM \& EIU 2010). Digital competencies, the level of skills in the EU are presented in the Digital Agenda (Chapter 4, EC 2013a). The lowest rate of computer skills was registered in Romania: only $35 \%$ of the population have some level of computer skills: $14 \%$ at low level, $13 \%$ at medium level, and $8 \%$ at high level (Herman 2012) ${ }^{4}$.

A strong positive relationship was obtained between the NRI, the level of egovernment development, and the government procurement of high technology; the calculated Spearman rank correlation is presented in Table 6. Countries with a high level of government procurement with advanced technology products have developed e-government also, as can be seen in Figure 10. A very strong positive relationship was found between the laws relating to ICT and government procurement of advanced technology products (Spearman rank correlation $\rho=$ $0.821, \mathrm{p}<0.01)$. The obtained correlation confirms the fact that law is an engine of development.

$4 \quad$ Education and training represent a key success factor. The European Lifelong Learning Index (ELLI) is a composite indicator calculated on 36 indicators and evaluates the lifelong learning conditions in Europe (school-based, vocational, social, and learning for personal development). In the ranking, Romania is in the last place (17.31 score) and Denmark is the leader with an overall score of 75.65 (ELLI Index 2010). 
The successful adoption of e-government can be noted in countries with a high GDP/capita. Our results reveal a strong positive relationship (Table 7) between the level of economic development measured in GDP/capita and the level of development of the knowledge economy (KEI), information society (IDI), the technological and network preparedness of the countries in order to benefit from ICT (e-readiness, NRI, ICT, ICT-OI), knowledge (KI), and innovation (SII provided by $\mathrm{EC}$ and innovation provided by WB).

\section{THE USE OF ANALYTICAL HIERARCHY PROCESS (AHP) FOR PRIORITISING FACTORS WITH THE HIGHEST OVERALL IMPACT ON THE SUCCESSFUL IMPLEMENTATION OF E-GOVERNMENT}

A successful, efficient implementation of e-government needs a developed knowledge-based economy which creates a favourable environment for the information society. It means the "simultaneous maximisation" of the objectives of the social, governance and economic capabilities. This approach suggests that this is all about a multi-dimensional concept characterised by a high degree of conflict. In these cases, the Analytic Hierarchy Process (AHP), which is a multicriteria decision analysis, would be the most useful instrument to solve problems with multiple conflicting and subjective criteria. The AHP method was introduced by Saaty (2000). In the last decade, many studies have been published, with the application of the method in different fields (Alessio - Ashraf 2009; Forman - Gass 2001).

The pairwise comparison matrix was built at each node of the hierarchy, by comparing the relative importance with respect to the goal. The priorities make sense only if the matrix is consistent. The consistency ratio, CI, was introduced by Saaty, who demonstrated that it must be less than 0.1. AHP allows the evaluation of quantitative as well as qualitative criteria on the same preference scale of 9 levels. A numerical scale was used. The evaluation usually follows logics and rationale. The hierarchy and evaluation reflect the authors' point of view; the aim is to prove that AHP can be a useful instrument for policymakers to prioritise the options. The comparisons are recorded in a positive, reciprocal matrix. The elements of the matrix reflect the intensity of the importance between the criteria.

To answer our Question 4, the identified key success factors were first grouped into categories and arranged in a hierarchical relationship. Next, we identified the categories/dimensions that had the greatest impact on e-government efficiency and on successful implementation; which priorities policymakers must be focused on in order to achieve this goal, how can options be prioritised and ranked so that the overall goal may be achieved in the shortest/minimum time period? 
The formulated decision problem was organised into a hierarchy of four levels (L1, L2, L3, and L4). Each level has multiple nodes with respect to which the alternatives on the next level are compared, as can be seen below and in Figure 11:

L1 Economic dimension/environment

- enablers (human resources-level of education, computer and internet skills; finance and support $R \& D$ expenditure in public administration, training for employees; online availability of services; connectivity and technology infrastructure [hard, soft, networking]; technology absorption; infrastructure availability)

- activities in public administration, local and central level (government investment, public-private partnership; capacities, public sector innovation, financial and human resources; education, skills of government employees; G2G connectivity/communication performance)

- output (government procurement of advanced technology products; impact on businesses; impact of digitisation on the growth of the economy [GDP, job creation, innovation]; productivity of services; centres of ICT competencies in public administration; benefits from ICT usage; use of internet by consumers)

\section{L2 Socio-cultural dimension/environment}

- equity/competencies/e-inclusion (eliminate exclusion due to age, education, place of residence, disability in case of employee, citizens, businesses; internet usage, computer skills, safety nets; individuals using internet)

- promotion/ICT usage (centre for information; education level of the population; credibility; e-services absorption, internet literacy)

- access/internet (employee competencies, technical skills; popularisation of benefits; uptake; intensity; network)

- impact of digitisation on society, well-being of the country (quality of life; access to basic services)

\section{L3 Institutional dimension/environment-government policy and vision}

- government prioritisation of ICT, effectiveness (expenditures on ICT as a percentage of GDP; importance of ICT in government vision; transparency; inequality-adjusted education)

- quality of services - ICT demand; availability of online public services for citizens; availability of online public services for businesses

- e-participation (ICT use and government efficiency)

- competencies (e-government leadership and visionaries; e-government strategy; digital development strategy; adoption of new management models in government units; top management support; extent of staff training) 


\section{L4 Legal environment}

- laws covering the internet

- effectiveness of the traditional legal framework (level of censorship, effectiveness of law-making bodies)

- ease of registering a new business

- judicial independence

The overall preference matrix (OPM), built up on our judgment, can be seen in Table 8 .

Table 8. The overall preference matrix (OPM)

\begin{tabular}{l|c|c|c|c}
\hline OPM & Economic & Socio-cultural & Institutional & Legal \\
\hline Economic & 1 & 3 & 2 & 1.5 \\
\hline Socio-cultural & $1 / 3$ & 1 & $1 / 2$ & $1 / 2$ \\
\hline Institutional & $1 / 2$ & 2 & 1 & $1 / 2.5$ \\
\hline Legal & $1 / 1.5$ & 2 & 2.5 & 1 \\
\hline
\end{tabular}

Source: Own calculation by Expert Choice software package.

Next, the relative weights will be calculated using the eigenvalue method. The principal eigenvector of the matrix shows the relative importance of the factors. The eigenvector of the matrix is: $\mathrm{V}_{\mathrm{OPM}}=(0.387,0.122,0.182,0.310)$ and $\mathrm{CI}=$ 0.03 less than 0.1 . Thus, the calculated priorities, in concordance with the calculated weights, are as follows: economic dimension (EC), legal framework (LEG), the vision and policy of the government (INS), and the socio-cultural (SC) environment. The comparison (judgment) matrix at each level of hierarchy is presented below.

Table 9. The comparison (judgment) matrix

\begin{tabular}{l|c|c|c}
\hline Economic & Enablers & Activities & Output \\
\hline Enablers & 1 & 2 & 3 \\
\hline Activities & & 1 & 1.5 \\
\hline Output & & & 1 \\
\hline
\end{tabular}

Source: Own calculation by Expert Choice software package.

Table 10. The comparison (judgment) matrix

\begin{tabular}{l|c|c|c|c}
\hline Socio-cultural & Equity & Promotion & Access & Impact \\
\hline Equity & 1 & 2 & 1.5 & $1 / 3$ \\
\hline Promotion & & 1 & $1 / 1.5$ & $1 / 4$ \\
\hline Access & & & 1 & $1 / 3$ \\
\hline Impact & & & & 1 \\
\hline
\end{tabular}

Source: Own calculation by Expert Choice software package. 
Table 11. The comparison (judgment) matrix

\begin{tabular}{|l|c|c|c|c|}
\hline Institutional & Priorit ICT & Quality & e-participation & Compet. \\
\hline Priorit ICT & 1 & $1 / 2$ & $1 / 4$ & $1 / 2.5$ \\
\hline Quality & & 1 & $1 / 1.5$ & 2 \\
\hline e-participation & & & 1 & 2 \\
\hline Competencies & & & & 1 \\
\hline
\end{tabular}

Source: Own calculation by Expert Choice software package.

Table 12. The comparison (judgment) matrix

\begin{tabular}{|l|c|c|c|c|}
\hline Legal & Laws ICTs & Traditional & Busin reg. & Jud. indep. \\
\hline Laws ICTs & 1 & 3 & 3 & 2 \\
\hline Traditional & & 1 & $1 / 1.5$ & $1 / 2$ \\
\hline Business reg. & & & 1 & $1 / 2.5$ \\
\hline Jud. indep. & & & & 1 \\
\hline
\end{tabular}

Source: Own calculation by Expert Choice software package.

The obtained consistency indices fulfill the condition and the obtained eigenvectors are considered the local weight of the nodes. The global weights gave the final overall prioritisation as can be seen in Figure 12.

The ranking of the criteria (Figure 12) shows the priorities for decision-makers in order to improve the level of e-government development in transition economies. The Expert Choice software package permits a sensitivity analysis. The weights of the criteria can be varied as input data. In this way, it can be observed

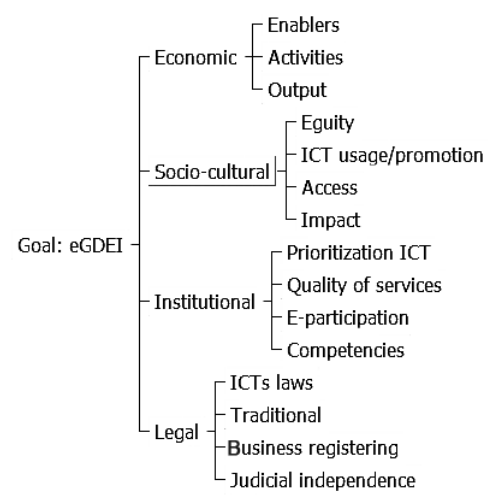

Figure 11. The hierarchy by Expert Choice software package

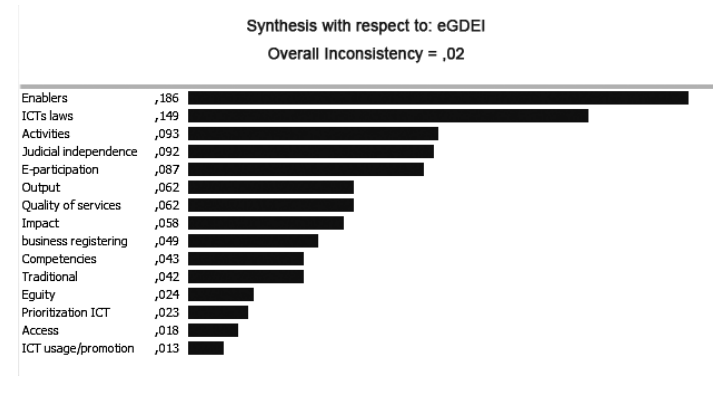

Figure 12. The final overall prioritisation

Source: Own calculation by Expert Choice software package. 
how the corresponding criteria will change, how the relationship between the elements is changing. The 4 main criteria (percentage) can be increased interactively and so it can be registered how the sub-criteria change. Thus, the impact of the criteria on the sub-criteria can be analysed.

\section{CONCLUSIONS}

Despite using different sources (World Bank, Economist Intelligence Unit, United Nations, European Commission, World Economic Forum) to gather data about the level of e-government development, the transition countries were ranked nearly in the same order. The calculated Spearman rank correlation coefficient justified this fact as well, showing that a strong or very strong relationship exists between the variables. The results reveal that the indicators reflect an accurate image of the level of e-government development. The correlation matrix, which was calculated to evaluate the intensity of connection between the variables, shows statistically significant strong correlations.

The diversity of the factors and the relationship between them suggest that the adoption of e-government is a great challenge. It is essential to take into account that not only technical barriers must be eliminated, but also the mentality of individuals.

Policymakers can directly influence e-government. The analytical hierarchy process (AHP) can be a useful instrument for policymakers in this process. The paper showed qualitative and quantitative criteria in the created AHP hierarchy. The prioritisation by AHP means the identification of the criteria with the highest overall impact on the successful implementation of e-government.

In our model the level of the hierarchy was imposed by the used software. The free version of Expert Choice software permits a limited dimension of the structure, only a three-level hierarchy. In order to implement the proposed method in practice, a more complex structure can be created. To elaborate a complex hierarchy for each transition economy would be an interesting topic for future research. The sensitivity analyses permit an overview on the interdependence of the key success factors, and show how the indicators influence each other. 


\section{REFERENCES}

Alessio, I. - Ashraf, L. (2009): Analitic Hierarchy Process and Expert Choice: Benefits and Limitations. ORInsight, 22(4): 201-220.

Andoh-Baidoo, F. K. - Lawrencia, A. (2011): Examining the Preparedness of an Emerging Economy towards E-Government Implementations: Swot Analysis. Southwest Decision Sciences Institute Conference, Houston: University of Louisiana at Lafayette. http://www.swdsi.org/ swdsi2011/2011_SWDSI_Proceedings/papers/papers/PA178.pdf.

Bilbao-Osorio, S. - Dutta, S. - Lanvin, B. (2013): The Global Information Technology Report. Geneva: WEF and INSEAD.

Chilea, D. (2004): European Regulation of Electronic Commerce. The Juridical Current, (1-2): $81-98$.

Cuervo, V. M. - Menéndez, L. J. (2005): Inequalities in the Information Society: A Statistical Approach to the Digital Divide. In: First Meeting of the Society for the Study of the Economic Inequality, pp. 1-11. Palma de Mallorca, Spain: Universitat de les illes Balears; http://www.uib. es/congres/ecopub/ecineq/papers/257vincente-lopez.pdf

Danish, D. (2006): E-Readiness for Developing Countries: Moving the Focus from the Environment to the Users. The Electronic Journal on Information Systems in Developing Countries, 27(6): $1-14$.

EBRD (2012): Transition Report. Integration across Borders. London.

EC (2013a): Digital Agenda Scoreboard 2013. (Retrieved January 5, 2014) https://ec.europa.eu/digital-agenda/sites/digital-agenda/files/DAE\%20SCOREBOARD\%202013\%20-\%20SWD\%20 2013\%20217\%20FINAL.pdf

EC (2013b): ICT2013 - eGovernment in the Spotlight. (Retrieved January 14, 2014), http:// ec.europa.eu/digital-agenda/en/: http://ec.europa.eu/digital-agenda/en/news/ict2013-egovernment-spotlight

ELLI Index 2010. http://www.elli.org/

Forman, H. E. - Gass, I. S. (2001): The Analytic Hierarchy Process - An Exposition. Operations Research, 49(4): 469-486.

Gatman, A. (2011): E-Government - Assisting Reformed Public Administration in Romania. Romanian Journal of Economics, 32(1-41): 216-242.

Herman, E. (2011): Education's Impact on the Romanian Labour Market in the European Context. Procedia - Social and Behavioural Science Journal, 46(12): 5563-5567.

Hollanders, H. - Es-Sadki, N. (2013): Innovation Union Scorebord 2013. Belgium: European Comission, UNU-MERIT, http://ec.europa.eu/enterprise/policies/innovation/files/ius-2013 en.pdf

Hollanders, H. - Arundel, A. - Buligescu, B. - Peter, V. - Roman, L. - Simmonds, P. (2013): European Public Sector Innovation Scoreboard. Belgium: UNU-MERIT, European Commission.

IBM - EIU (2009): E-readiness Rankings 2009, The Usage Imperative. http://graphics.eiu.com/ pdf/E-readiness\%20rankings.pdf: IBM Institute for Business Value; The Economist Intelligence Unit.

IBM - EIU (2010): Digital Economy Rankings. Institute for Business Value, Economist Intelligence Unit. http://www-935.ibm.com/services/us/gbs/bus/pdf/eiu_digital-economy-rankings2010_final_web.pdf: IBM

Ifinedo, $\bar{P}$. - Singh, M. (2011): Determinants of e-Government Maturity in the Transition Economies of Central and Eastern Europe. Electronic Journal of e-Government, www.ejeg.com, 166-182. 
ITU (n.d.): ICT Data and Statistics. (Retrieved December 10, 2013). http://www.itu.int/ITU-D/ict/ publications/idi/material/2007/table1_2007.html\#upper

ITU (n.d.): ICT Data and Statistics.(Retrieved December 28, 2013). http://www.itu.int/ITU-D/ict/ publications/idi/material/2007/table1_2007.html\#upper

ITU (2013): Measuring the Information Society. Executive summary. (Retrieved January 7, 2014). http://www.itu.int/dms_pub/itu-d/opb/ind/D-IND-ICTOI-2013-SUM-PDF-E.pdf

Jindřich, S. (2013): Knowledge Economy and Innovation Indices: Their Concordance and Diversity. In: The 7th International Days of Statistics and Economics, pp. 1295-1303. Prague: University of Economics.

Kenny, B. - Trick, B. (1994): Reform and Management Education. A Case of Czech Republic. Journal of East - West Business, 1(1): 69-95.

KPMG - ODI (2012): The Change Readiness Index. http://www.kpmg.com/Global/en/IssuesAnd Insights/ArticlesPublications/change-readiness/Documents/change-readiness-index.pdf: KPMG, ODI.

Matei, A. - Savulescu, C. (2011): E-government in the Balkans. Comparative Study. APAS - Academic Public Administration Studies, http://www.apas.admpubl.snspa.ro/handle/2010/388, 1-16.

Saaty, L. T. (2000): Fundamentals of Decision Making. Pittsburg: RWS Publication, University of Pittsburg.

Schwab, K. - WEF (2013-2014): Global Competitiveness Index. Geneva: http://reports.weforum. org/the-global-competitiveness-report-2013-2014/

Selhofer, H. - Mayringer, H. (2001): Benchmarking the Information Society Development in European Countries. Communications - Strategies, 43(3):17.

Soukup, J. (2013): Knowledge Economy and Innovation Indices: Their Concordance and Diversity. In: The 7th International Days of Statistics and Economics, pp. 1295-1303. Prague: University of Economics.

Spremić, M. - Šimurina, J. - Jaković, B. - Ivanov, M. (2010): E-Government in Transition Economies. International Journal of Social Sciences, 5(2): 82-90.

Suutari, V. - Riusala, K. (2001): Leadership Styles in Central Eastern Europe: Experiences of Finnish Expatriates in the Czech Republic, Hungary and Poland. Scandinavian Journal of Management, 17: 249-280.

Szabo, K. Zs. - Soltes, M. - Herman, E. (2013): Innovative Capacity - Performance of Transition Economies: Comparative Study at the Level of Enterprises. E-M Economics and Management, 1: 52-68.

UN (2012): E-Government Survey. New York: United Nations, Department of Economic and Social Affairs. http://unpan1.un.org/intradoc/groups/public/documents/un/unpan048065.pdf

UN (2014): E-Government Survey. http://unpan3.un.org. Retrieved January 10, 2014, from http:// unpan3.un.org/egovkb/egovernment_overview/ereadiness.htm

Vintar, M. - Decman, M. - Kunstelj, M. - Bercic, B. (2003): Integral E-government Development Indicators. Network of Institutes and Schools of Public Administration (NISPA) Conference, Budapest.

Weerakkodya, V. - El-Haddadeh, R. - Sabol, T. - Ghoneim, A. - Dzupka, P. (2012): E-government Implementation Strategies in Developed and Transition Economies: A Comparative Study. International Journal of Information Management, 32(1): 66-74.

Waseda University (2013): Waseda University International e-Government Ranking 2013. (Retrieved January 7, 2014) http://www.e-gov.waseda.ac.jp/pdf/Press_Released_on_e-Gov_ ranking_2013.pdf 
World Bank (2012): Knowledge Assessment Methodology. Knowledge for Development. (Retrieved December 14, 2013) http://info.worldbank.org/etools/kam2/: http://info.worldbank.org/etools/ kam2/KAM_page5.asp) http://web.worldbank.org/WBSITE/EXTERNAL/WBI/WBIPROGRAMS/KFDLP/EXTUNIKAM/0,menuPK:1414738 pagePK:64168427 piPK:64168435 th eSitePK:1414721,00.html

Zhiyuan, F. (2002): E-Government in Digital Era: Concept, Practice, and Development. International Journal of the Computer, the Internet and Management, 10(2): 1-22.

\section{APPENDIX}

DESCRIPTIVE STATISTICS

\begin{tabular}{l|r|r|r|r|r}
\hline & $\mathrm{N}$ & Minimum & Maximum & \multicolumn{1}{c}{ Mean } & Std. Deviation \\
\hline eGDI-UN & 27 & .61 & .91 & .7519 & .08907 \\
\hline KEI & 28 & 6.80 & 9.43 & 8.1425 & .72328 \\
\hline KI & 28 & 6.61 & 9.38 & 8.0300 & .75568 \\
\hline Economic incentive regime & 28 & 6.80 & 9.65 & 8.4746 & .77613 \\
\hline Innovation & 28 & 6.14 & 9.74 & 8.1943 & .98160 \\
\hline Education & 28 & 5.61 & 8.96 & 7.8468 & .91827 \\
\hline ICT & 28 & 6.19 & 9.49 & 8.0518 & .96322 \\
\hline SII & 28 & .19 & .75 & .4677 & .17263 \\
\hline Human Resources (HR) & 28 & .13 & .90 & .5748 & .15573 \\
\hline E-readiness & 25 & 5.07 & 8.87 & 7.1052 & 1.09585 \\
\hline IDI & 28 & 5.35 & 8.45 & 6.9171 & .86165 \\
\hline ICT Opportunity Index (ICT-OI) & 28 & 123.46 & 377.69 & 252.0832 & 72.90452 \\
\hline $\begin{array}{l}\text { Individuals with medium or high } \\
\text { internet skills }\end{array}$ & 27 & .25 & .62 & .4653 & .10258 \\
\hline $\begin{array}{l}\text { Individuals interacting online } \\
\text { with Public Authorities (PA) }\end{array}$ & 27 & .19 & .83 & .4685 & .15670 \\
\hline $\begin{array}{l}\text { Individuals returning filled } \\
\text { forms to PA }\end{array}$ & 27 & .08 & .75 & .3336 & .16115 \\
\hline $\begin{array}{l}\text { Enterprise returning filled } \\
\text { forms to PA }\end{array}$ & 27 & .35 & .99 & .7425 & .16199 \\
\hline NRI & 28 & 3.86 & 5.98 & 4.8025 & .64962 \\
\hline Laws relating to ICT (LAW-ICT) & 28 & 3.40 & 6.00 & 4.7457 & .69428 \\
\hline e-participation & 28 & .03 & 1.00 & .3996 & .26703 \\
\hline $\begin{array}{l}\text { Government procurement } \\
\text { of high tech }\end{array}$ & 28 & 2.70 & 4.60 & 3.5821 & .57093 \\
\hline GCI & 28 & 3700.00 & 63700.00 & 20864.2857 & 13820.84347 \\
\hline GDP per capita & & & & & \\
\hline
\end{tabular}

Source: Own calculations. 